\title{
Single-Diode PV CELl MODELING AND STUdY OF CHARACTERISTICS OF SINGLE AND TWO-DIODE EQUIVALENT CIRCUIT
}

\author{
Vivek Tamrakar, S.C. Gupta and Yashwant Sawle \\ Department of Electrical Engineering, M.A.N.I.T. Bhopal, Madhya Pradesh, India
}

\begin{abstract}
This paper presents characteristics of ideal single diode, practical single diode and two diode equivalent circuit models for modeling of solar photovoltaic cell. Then it presents non-linear mathematical equations necessary for producing $I-V$ and $P$-V characteristics from a single diode model. A flowchart has been made for estimation of cell current using Newton-Raphson iterative technique which is then programmed in MATLAB script file. A typical 120W polycrystalline solar module specifications have been used for model evaluation. The characteristic curves were obtained with the use of manufacturer's datasheet which shows the precise correspondence to the model.
\end{abstract}

\section{KEYWORDS}

Single Diode, Two Diode, I-V and P-V characteristics, solar irradiance.

\section{INTRODUCTION}

A large portion of energy is mainly extracted from the coal which is a limited source. Hence some alternate source of energy is required to compensate shortage of energy. A technology that directly converts free solar energy into electrical energy without causing any pollution to the environment is termed as photovoltaic power generation.

For the prediction of the behavior of a real solar cell under various environmental conditions and further to obtain its current-voltage (I-V) and power-voltage (P-V) characteristic curves, modeling of solar cell is necessarily required. The common approach is to utilize the electrical equivalent circuit, which is primarily based on a light generated current source connected in parallel to a p-n junction diode. Many models have been proposed for the simulation of a single solar cell or for a complete photovoltaic (PV) system at various solar intensities and temperature conditions [1-4].

Hence, modeling of solar cell is necessary for understanding its behavior under various atmospheric conditions. The key factor that affects the accuracy of the simulation and accurate representation of the nonlinear characteristics of the PV system is modeling [5]. There are different kinds of parametric models presented in various literatures in the past few decades, like single-diode model, two-diode model, three diode models, model with partial shading considerations and much more. The most commonly used models are single diode and two diode model, as they provide better relations with a practical solar cell keeping in mind the simplicity 
Electrical and Electronics Engineering: An International Journal (ELELIJ) Vol 4, No 3, August 2015

and the speed in the extraction of parameters as well as I-V and P-V curves also gives minimum error with respect to characteristics of solar PV cell.

Now, there are various kinds of single diode models described in previous literatures in past decades. They have been briefly discussed with its properties and limitations in the succeeding segment.

With the help of datasheet given by manufacturers indicating specifications of solar cell module and from set of non-linear equations, various unknown parameters necessary for modeling are estimated and respective characteristics have been produced.
$I_{p h} \quad$ Photocurrent (A)
$I_{o} \quad$ Diode saturation current (A)
$q \quad$ Electron charge, $1.6021 \times 10^{-19} \mathrm{C}$
$k \quad$ Boltzmann constant, $1.3865 \times 10^{-23} \mathrm{~J} / \mathrm{K}$
$T \quad$ Operating Temperature (Kelvin)
$n \quad$ Diode factor $(1 \leq \mathrm{n} \leq 2)$
$\mathrm{G} \quad$ Irradiance $\left(\mathrm{W} / \mathrm{m}^{2}\right)$
$R_{S} \quad$ Series resistance $(\Omega)$
$R_{p} \quad$ Shunt resistance $(\Omega)$
$n_{s} \quad$ Number of cells in series
$V_{o c} \quad$ Open circuit voltage
$I_{s c} \quad$ Short circuit current
$V_{m p} \quad$ Voltage at the maximal power point
$I_{m p} \quad$ Current at the maximal power point
$I_{d} \quad$ Current through the diode
I PV module current (A)
$\mathrm{V} \quad$ PV module voltage (V)
$E_{g} \quad$ Silicon gap energy of semiconductor
$v_{T} \quad$ Thermal voltage equivalent (V)
STC Standard temperature condition 
Electrical and Electronics Engineering: An International Journal (ELELIJ) Vol 4, No 3, August 2015

\section{Electrical Equivalent Circuits}

\subsection{Ideal Single Diode Model}

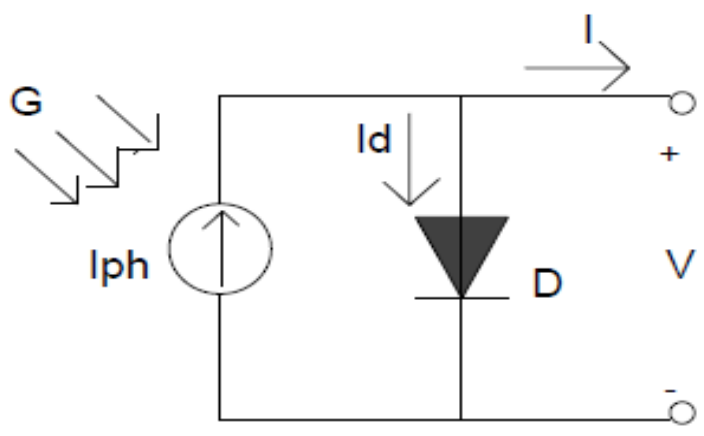

Figure 1. Ideal single diode model

This one is the most simplified form of an ideal PV cell through which the output voltage and current relations comes out to be,

$$
\begin{aligned}
& I=I_{p h}-I_{d} \\
& I_{d}=I_{o}\left(e^{\frac{V}{n_{s} v_{T}}}-1\right) \\
& v_{T}=\frac{n k T}{q}
\end{aligned}
$$

But this model doesn`t give accurate I-V and P-V curve characteristics.

\subsection{Practical Single Diode Model}

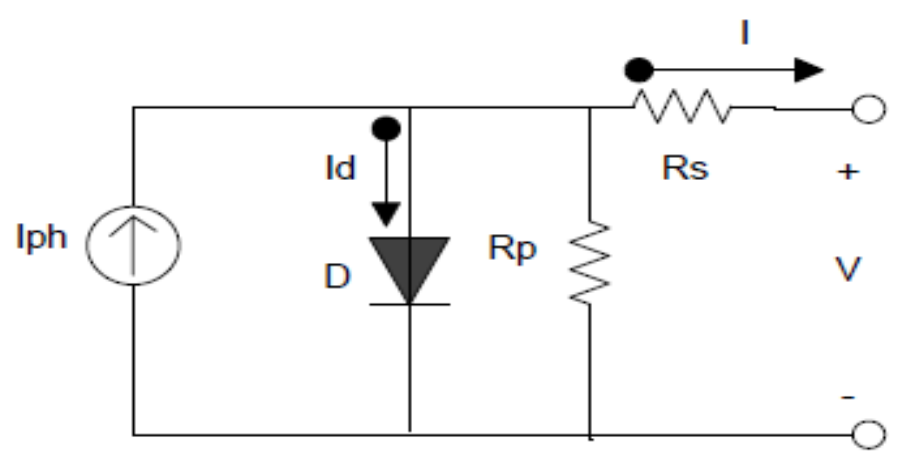

Figure 2. Practical single diode model 
Electrical and Electronics Engineering: An International Journal (ELELIJ) Vol 4, No 3, August 2015

This one is an equivalent circuit of a practical PV cell. In many literatures it is also termed as a five parameter model $\left(I_{o}, n, R_{s}, R_{p}, I_{p h}\right)$. It takes into account different properties of solar cell as:

- $\mathrm{R}_{\mathrm{S}}$ is in troduced as to consider the voltage drops and internal losses in due to flow of current.

- $\mathrm{R}_{\mathrm{P}}$ takes into account the leakage current to the ground when diode is in reverse biased.

- But this model has neglected recombination effect of diode, which is why it is still not the most accurate model.

$$
I=I_{p h}-I_{o}\left(e^{\frac{V+I R_{s}}{n_{s} v_{T}}}-1\right)-\frac{V+I R_{s}}{R_{p}}
$$

\subsection{Two Diode Model}

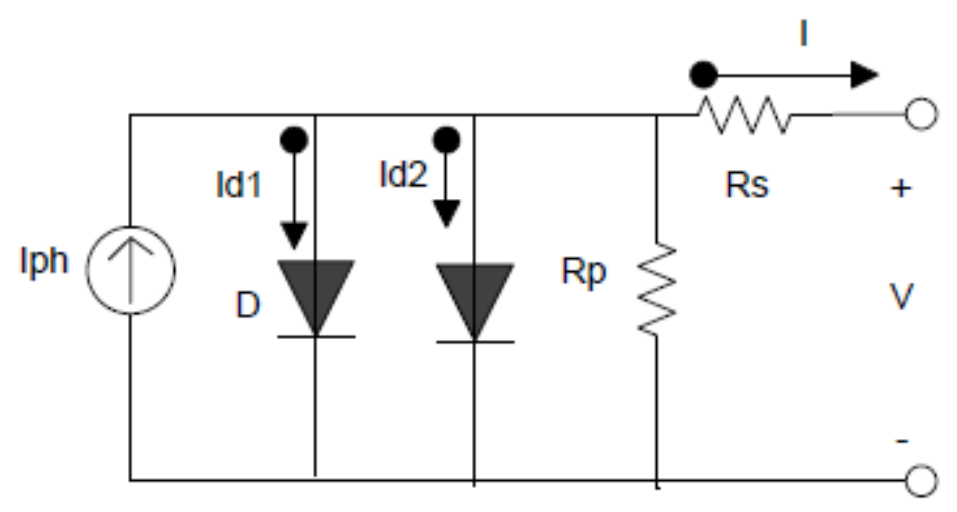

Figure 3. Two diode model

This is the modified form of single diode circuit which takes into account the effect of recombination by introducing another diode in parallel.

$$
I=I_{p h}-I_{o 1}\left(e^{\frac{V+I R_{S}}{n_{S 1} v_{T}}}-1\right)-I_{o 2}\left(e^{\frac{V+I R_{S}}{n_{S 2} v_{T}}}-1\right)-\frac{V+I R_{S}}{R_{p}}
$$

But now there will be two unknown diode quality factors. Hence no. of equations increases thereby making calculations more complex.

At lower values of irradiance and low temperatures, two diode model gives much more accurate curve characteristics as compared to single diode model. 
Electrical and Electronics Engineering: An International Journal (ELELIJ) Vol 4, No 3, August 2015

So taking all aspects into consideration, as far as mathematical computation and number of iterations are concerned, single diode model turns out to be fast results due to less complex equation and also computational errors are less unlike in case of two-diode model. The single diode model can be suitably used for power system planning purposes.

\section{Mathematical Equations For Plotting I-V And P-V Curves}

As current through $R_{P}$ is very less compared to other currents, value of $R_{P}$ has been assumed to be negligible for sake of simplicity in calculation.

Now, photocurrent and reverse saturation current are temperature dependent parameters as,

$$
I_{p h}=\left(I_{p h}\right)_{T_{1}}+K_{o}\left(T-T_{1}\right)
$$

Where, $T_{i}$ is a normal standard temperature.

$$
\begin{aligned}
& \left(I_{p h}\right)_{T_{1}}=\left(I_{S C}\right)_{T_{1}} \frac{G}{G_{S T C}} \\
& K_{o}=\frac{\left(I_{S c}\right)_{T_{2}}-\left(I_{S c}\right)_{T_{1}}}{T_{2}-T_{1}}
\end{aligned}
$$

The cell photocurrent is directly proportional to irradiance. Although cell performance does not degrade significantly but PV cell efficiency depends on incident solar energy.

$$
\begin{aligned}
& I_{o}=\left(I_{o}\right)_{T_{1}} \times\left(\frac{T}{T_{1}}\right)^{3 / n} \times e^{\frac{q(E g) T_{1}}{n k}\left(\frac{1}{T}-\frac{1}{T_{1}}\right)} \\
& \left(I_{o}\right)_{T_{1}}=\frac{\left(I_{s c}\right)_{1}}{\left(e^{\frac{q\left(V_{o c}\right)_{1}}{n k T_{1}}}-1\right)}
\end{aligned}
$$

The value of series resistance can be estimated by,

$$
\begin{aligned}
& R_{s}=-\left(\frac{d V}{d I}\right)_{V_{o c}}-\frac{1}{X_{v}} \\
& X_{v}=\left(I_{o}\right)_{T_{1}} \frac{q}{n k T_{1}} e^{\frac{q\left(V_{o c}\right)_{1}}{n k T_{1}}}-\frac{1}{X_{v}}
\end{aligned}
$$


Electrical and Electronics Engineering: An International Journal (ELELIJ) Vol 4, No 3, August 2015

The flowchart for estimation of cell current with irradiance, temperature and cell voltage as input parameters is as shown in Fig. 4. The cell voltage must be an array whose range should cover all possible values PV cell is able to produce under specified conditions from manufacturers.

The ratio of the maximum power that can be delivered to the load and the product of $I_{S C}, V_{O C}$ is termed as fill factor. It is a measure of the real I-V characteristics. For value of 0.7 or higher are considered as good cells. FF increases with decrease in temperature.

$$
F F=\frac{P_{\max }}{V_{o c} I_{s c}}=\frac{V_{m p} I_{m p}}{V_{o c} I_{s c}}
$$

From I-V characteristics of PV cell, at extreme points, from (4), it changes to, At open circuit condition,

$$
0=I_{p h}-I_{o}\left(e^{\frac{V_{o c}+I R_{S}}{n_{S} v_{T}}}-1\right)-\frac{V_{o c}+I R_{S}}{R_{p}}
$$

At short circuit condition,

$$
I_{s c}=I_{p h}-I_{o}\left(e^{\frac{I_{S c} R_{S}}{n_{s} v_{T}}}-1\right)-\frac{I_{s c} R_{s}}{R_{p}}
$$

At maximum power point condition,

$$
I_{m p}=I_{p h}-I_{o}\left(e^{\frac{V_{m p}+I_{m p} R_{s}}{n_{s} v_{T}}}-1\right)-\frac{V_{m p}+I_{m p} R_{s}}{R_{p}}
$$

By using above equations solar PV cell characteristics can be produced. 
Electrical and Electronics Engineering: An International Journal (ELELIJ) Vol 4, No 3, August 2015

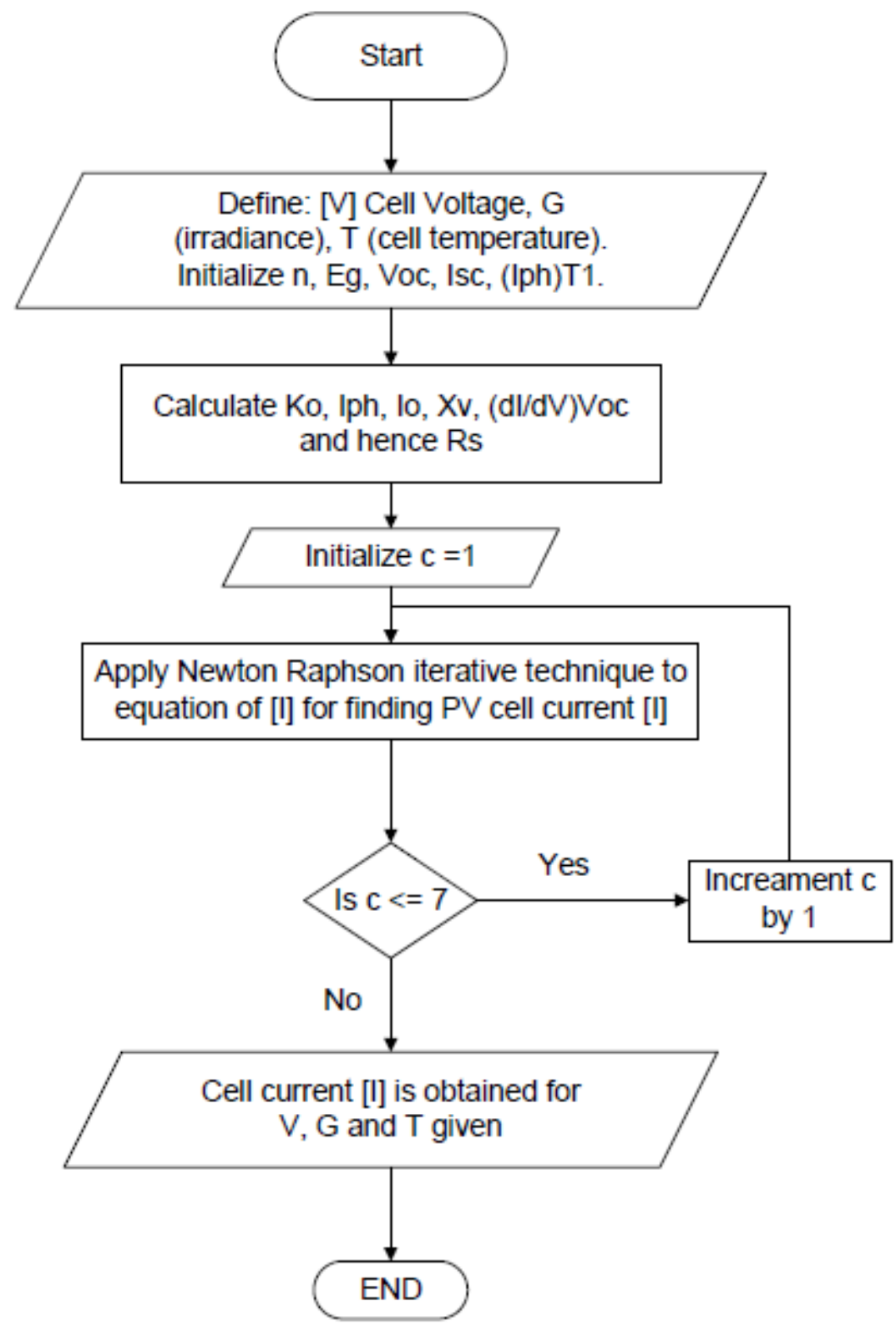

Figure 4. Flowchart for cell current calculation

\section{Modeling of The PV Module}

The BP Solarex MSX-120 polycrystalline PV module was chosen for modeling. It provides 120 Watt of nominal maximum power and consists of 36 series connected Cr-Si type PV cells. Its specifications are shown in Table 1. By using MATLAB program the PV module was implemented using flowchart. 
Table 1.

\begin{tabular}{|l|l|}
\hline \multicolumn{1}{|c|}{ Electrical Parameters } & \multicolumn{1}{c|}{ BP MSX-120W } \\
\hline Voltage Configurations & 12 or $24 \mathrm{~V}$ \\
\hline Nominal power rating $\left(\mathrm{P}_{\mathrm{m}}\right)$ & $120 \mathrm{~W}$ \\
\hline $\mathrm{V}_{\mathrm{mp}}$ & $17.1 \mathrm{~V}$ \\
\hline $\mathrm{I}_{\mathrm{mp}}$ & $7.0 \mathrm{~A}$ \\
\hline $\mathrm{I}_{\mathrm{sc}}$ & $7.6 \mathrm{~A}$ \\
\hline $\mathrm{V}_{\mathrm{cc}}$ & $21.3 \mathrm{~V}$ \\
\hline Number of cells in series & 36 \\
\hline Weight & $14.0 \mathrm{Kg}$ \\
\hline
\end{tabular}

The necessary parameters are evaluated and assumptions have been made during execution of equations listed in previous section. This program takes irradiance, cell temperature and PV module voltage as inputs and with the help of equations it returns output current value of PV module.

\section{RESULTS AND DISCUSSIONS}

The plots of I-V characteristic curves have been produced by varying certain parameters one at a time keeping other parameters constant at STC from flowchart implemented in MATLAB script file. Fig. 5 describes I-V characteristic for varying solar irradiance value G (at STC $1000 \mathrm{~W} / \mathrm{m}^{2}$ ). On observing the curve we see that with increase in irradiance values cell current value also increases proportionally but cell voltage increases very less. Fig. 6 describes I-V characteristics for varying temperature $\mathrm{T}$. It is observed that as temperature increases cell current also increases slightly and cell voltage shows significant decrease in its value. Likewise in Fig. 7 and Fig. 8 diode quality factor and series resistance is varied respectively. The reverse saturation current is temperature dependent parameter and also depends on quality factor of diode. There are two more plots in Fig. 9 and Fig. 10 are showing P-V characteristics of solar cell through which we can locate its peak i.e. maximum power point with respective voltages for varying irradiance and temperature respectively. And it is being observed that as irradiance increases output power also increases and reaches nominal power point at STC. Also, with increase in temperature, output power decreases. 
Electrical and Electronics Engineering: An International Journal (ELELIJ) Vol 4, No 3, August 2015

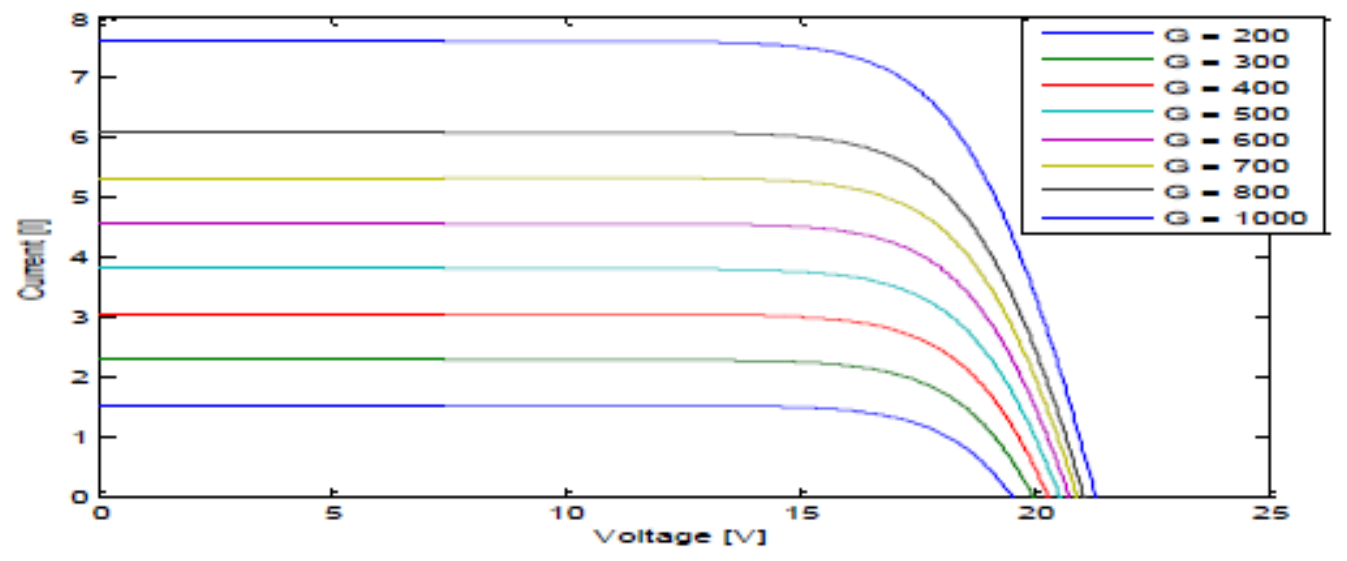

Figure 5. I-V characteristics for varying irradiance $\mathrm{G}(\mathrm{W} / \mathrm{m} 2)$

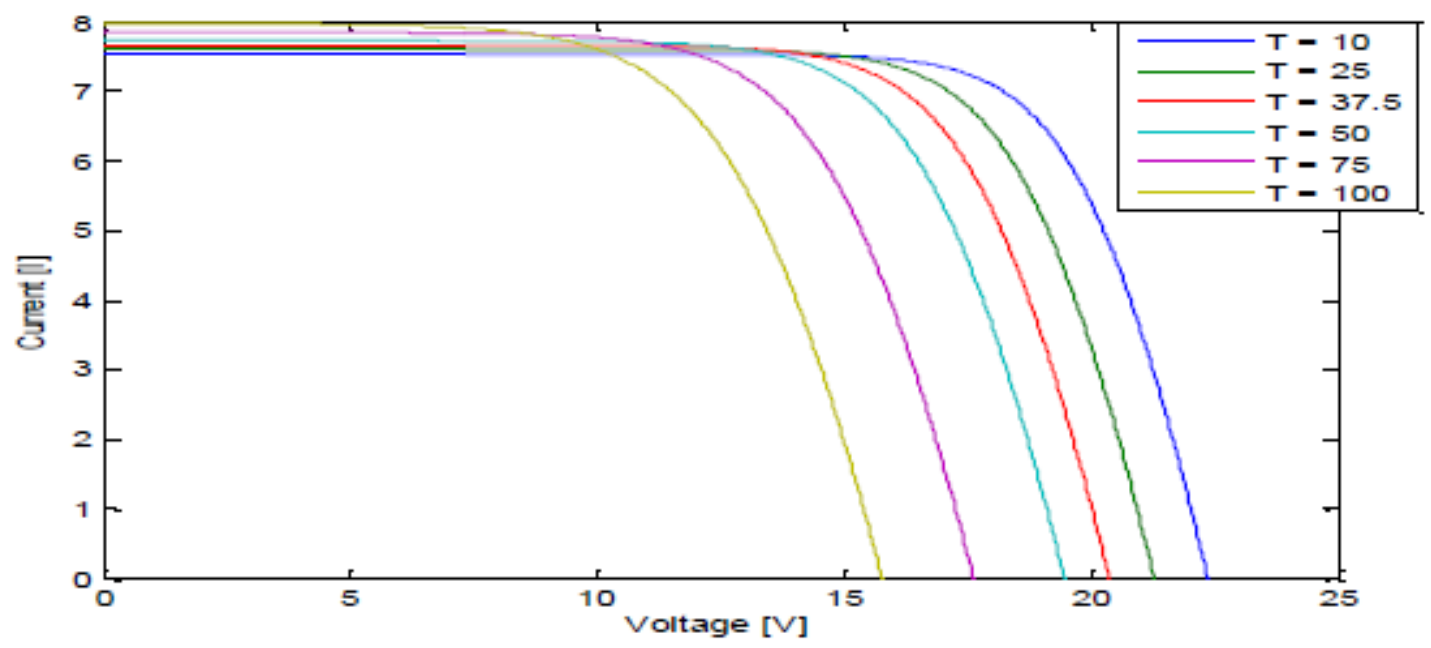

Figure 6. I-V characteristics for varying temperature $\mathrm{T}$ ( Celcius ) 
Electrical and Electronics Engineering: An International Journal (ELELIJ) Vol 4, No 3, August 2015

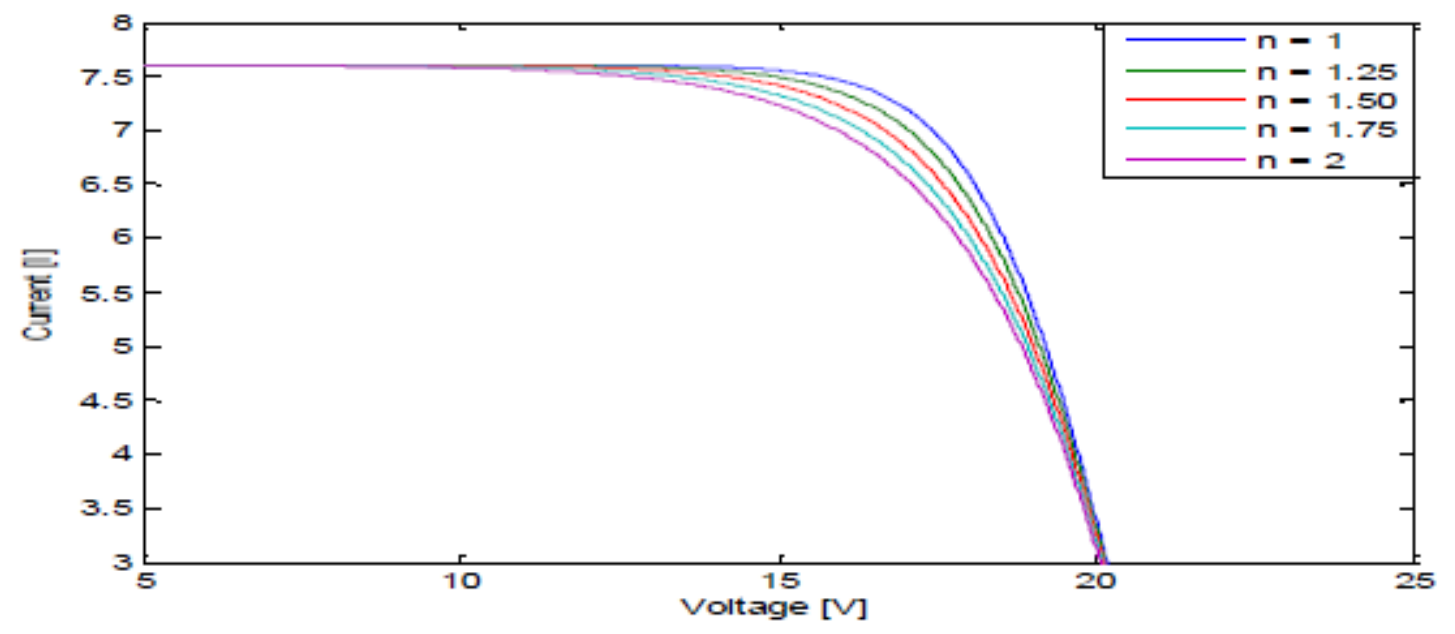

Figure 7. I-V characteristics for varying diode quality factor $n$

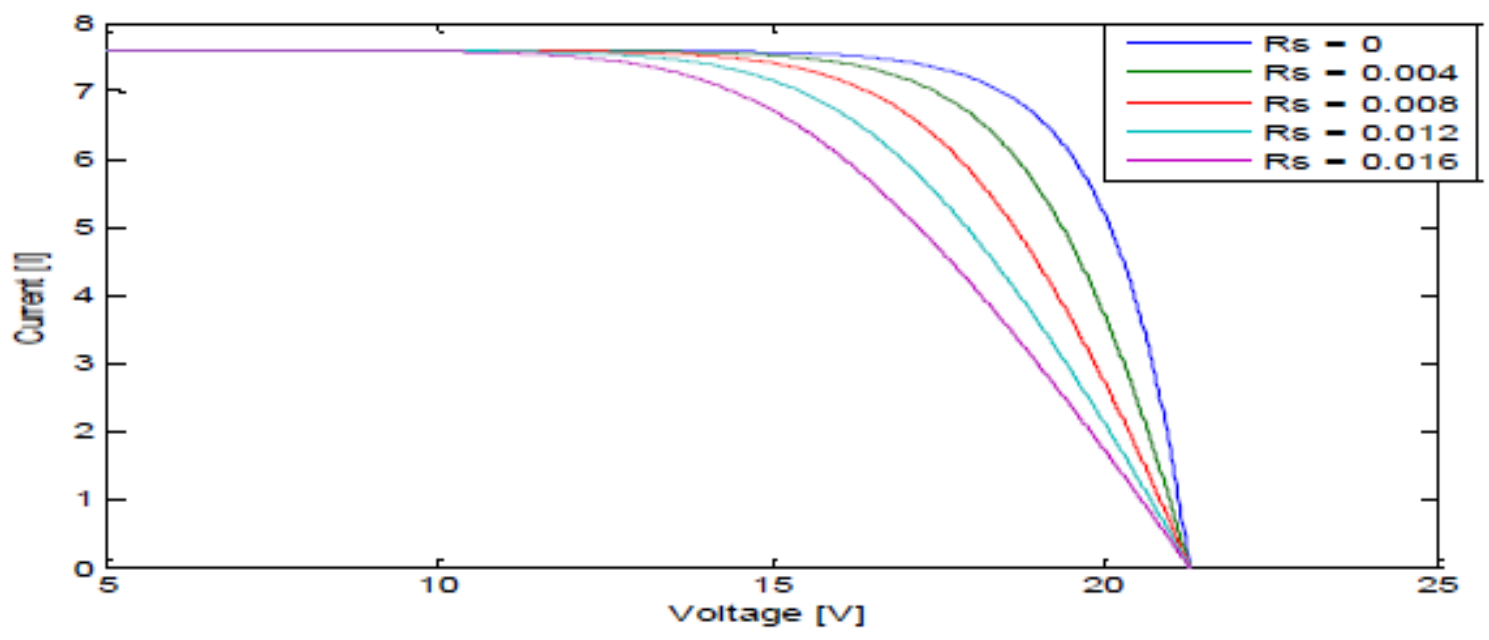

Figure 8. I-V characteristics for varying series resistance Rs(ohms) 
Electrical and Electronics Engineering: An International Journal (ELELIJ) Vol 4, No 3, August 2015

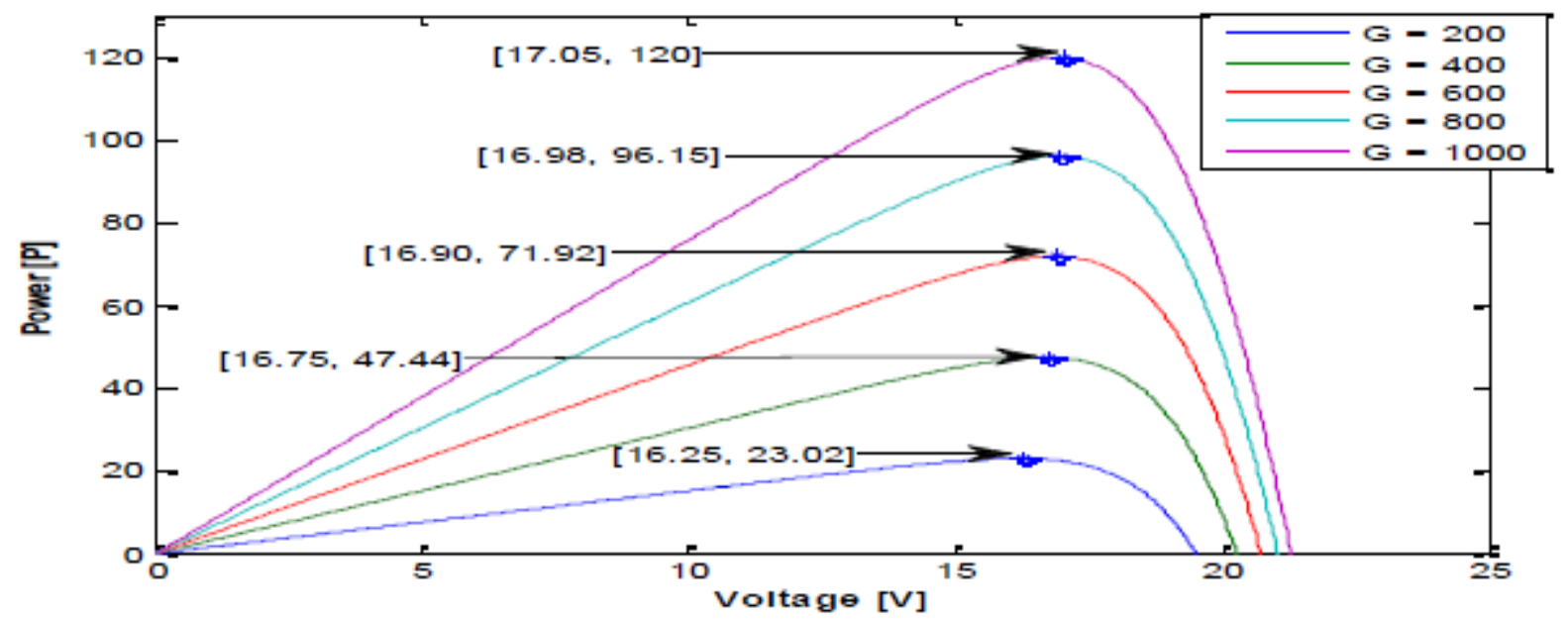

Figure 9. P-V characteristics for varying irradiance $\mathrm{G}(\mathrm{W} / \mathrm{m} 2)$

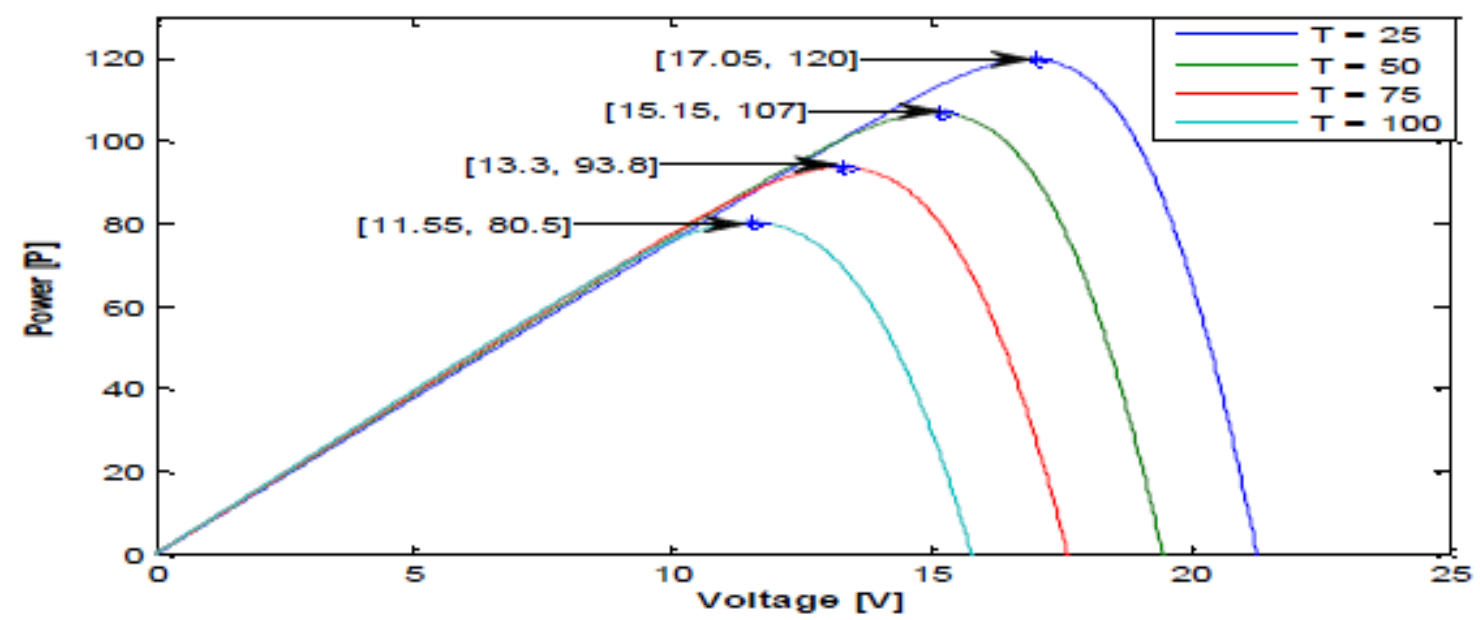

Figure 10. P-V characteristics for varying temperature T(celcius)

\section{CONCLUSIONS}

The single diode model gives much acceptable results in various conditions within less iteration as demonstrated using a flowchart in Matlab for a typical BP solarex MSX-120W solar panel. For a given solar insolation and temperature, the program estimates the current for a given set of voltages. The results from the Matlab model shows excellent correspondence to manufacturer's data from datasheet. This model so developed was used to show effect in I-V characteristics of temperature, insolation, resistance, ideality factor and series resistances. The main objective of this paper was to show that single diode modeling is the most suitable model which can be used for simulating electrical behavior of PV module system for planning purposes in the field of power system. 
Electrical and Electronics Engineering: An International Journal (ELELIJ) Vol 4, No 3, August 2015

\section{REFERENCES}

[1] Saloux Etienne, Teyssedou Alberto, Sorin Mikhaïl. "Explicit model of photovoltaic panels to determine voltages and currents at the maximum power point". Sol Energy 2011;85(5), pp. 713-22.

[2] Ishaque Kashif, Salam Zainal, Taheri Hamed. "Simple, fast and accurate two diode model for photovoltaic modules”. Sol Energy Mater Sol Cells 2011;95(2), pp. 586-94.

[3] Tsai Huan-Liang. "Insolation-oriented model of photovoltaic module using Matlab/simulink". Sol Energy 2010;84(7), pp.1318-26.

[4] Gow, J.A.; Manning, C.D., "Development of a photovoltaic array model for use in power-electronics simulation studies," Electric Power Applications, IEE Proceedings - , vol.146, no.2, pp.193-200, Mar 1999 doi: 10.1049/ip-epa:19990116.

[5] Yetayew, T.T.; Jyothsna, T.R., "Improved single-diode modeling approach for photovoltaic modules using data sheet," India Conference (INDICON), 2013 Annual IEEE , vol., no., pp.1-6, 13-15 Dec. 2013 doi: 10.1109/INDCON.2013.6726092.

[6] Besheer, A.H.; Abdelaziz, A.Y., "A comparative analysis for different kinds of single diode model photovoltaic module," Innovative Smart Grid Technologies - Asia (ISGT Asia), 2014 IEEE , vol., no., pp.41-46, 20-23 May 2014.

[7] Hyeonah Park; Hyosung Kim, "PV cell modeling on single-diode equivalent circuit," Industrial Electronics Society, IECON 2013 - 39th Annual Conference of the IEEE, vol., no., pp.1845-1849, 10-13 Nov. 2013.

[8] Suthar, M.; Singh, G.K.; Saini, R.P., "Comparison of mathematical models of photo-voltaic (PV) module and effect of various parameters on its performance," Energy Efficient Technologies for Sustainability (ICEETS), 2013 International Conference on , vol., no., pp.1354-1359, 10-12 April 2013.

[9] Filippo Attivissimo, Francesco Adamo, Alessio Carullo, Anna Maria Lucia Lanzolla, Filippo Spertino, Alberto Vallan. "On the performance of the double diode model in estimating the MPP for different photovoltaic technologies”. Measurement 46 (2013) pp.3549-3559.

[10] BP SOLAREX MSX-120W PV module datasheet. www.altestore.com

\section{AUTHORS}

Vivek Tamrakar1 Completed B.E. from SSCET Bhilai, Chhattisgarh in 2012. I am currently pursuing M.Tech from MANIT Bhopal, Madhya Pradesh.

Dr. S.C. Gutpa 2 received $\mathrm{PhD}$ degree in Electrical engineering from RGPV, Bhopal (2010), Currently he is Associate professor. His research interest includes Renewable Energy System and Power System Analysis

Yashwant Sawle3 received BE degree in Electrical engineering from SATI Vidisha MP, (2006), and M.Tech degree in Power System (2010) from MANIT, Bhopal. At the moment he is Pd.D. scholar at MANIT, Bhopal, India.

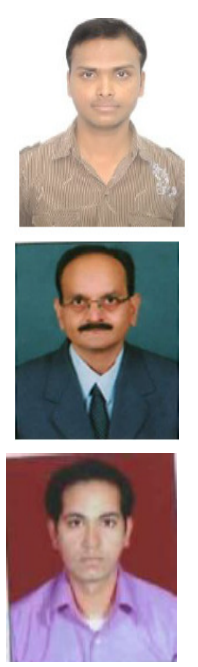

